\title{
Fecundity and egg size of grey-eel catfish Plotosus canius (Hamilton, 1822) from the coastal waters of Kampong Telok, Negeri Sembilan, Peninsular Malaysia
}

\begin{abstract}
Despite the vast researches on catfish species in Malaysia, Plotosus canius, the grey- eel catfish which is primarily found throughout the coastal seas of Malaysia has been neglected. No single published work on aspects of biology, especially its reproductive biology is available. In this study, fecundity and egg size of P. canius from coastal waters of Kampong Telok, Malaysia were studied. A total of 32 gravid females were used in the study. The mean fecundity of the female having a length of $50.28 \mathrm{~cm}$ and a wet body weight of $680 \mathrm{~g}$ was estimated to be 865 eggs. Fecundity was found to show positive relationship with total length $(\mathrm{r}=0.379)$, body weight $(\mathrm{r}=0.494)$ and gonad weight $(\mathrm{r}=0.336)$ but the values were not statistically significant $(\mathrm{p}>0.05)$. Egg diameter $(\mathrm{mm})$ among the various length groups showed a polymodal distribution but the differences were statistically significant $(\mathrm{p}>0.05)$. This study being the first attempt to gather information of P. canius in Malaysia would form a basis for future works of this catfish.
\end{abstract}

Keyword: Plotosus canius; Fecundity; Coastal seas; Egg diameter; Peninsular Malaysia 